\title{
THE TRAGEDY IN ABEYANCE OF CÁNDIDA. EMIGRATION AND ASSIMILATION IN THE CINEMA OF NINÍ MARSHALL
}

\author{
Marta Pérez Pereiro \\ Silvia Roca Baamonde \\ Universidade de Santiago de Compostela
}

Data recepción: 2018/09/21

Data aceptación: 2019/08/07

Contacto autoras: marta.perez.pereiro@usc.es; silvia.roca@usc.es

ORCID: https://orcid.org/0000-0002-5260-4485

ORCID: https://orcid.org/0000-0002-8623-0119

\section{RESUMEN}

Jean Epstein explicaba poéticamente que todo film contiene una "tragedia en suspenso" que no está explícita en la narrativa. Esta idea cinemática guía el análisis de los films Cándida (1939) y Cándida millonaria (1941), dos de las tres comedias sobre una criada gallega en Buenos Aires dirigidas por Luis Bayón Herrera. Niní Marshall interpreta el papel de Cándida, una recién llegada a Argentina que retrata en imágenes el estereotipo de la gallega emigrante. En los films, Cándida se enfrenta a la tragedia de la recién llegada a una sociedad extraña y la tragedia de la asimilación que pone en peligro la identidad de la emigrante que quiere encajar en la nueva sociedad. Este artículo explora la representación, a través de la fotogenia descrita por Epstein, la representación del "otro" invisible -mujer, inmigrante, trabajadora doméstica y parte de una minoría étnica- y las contradicciones implícitas en su retrato cómico.

Palabras clave: cine, emigración, asimilación, Galicia, Jean Epstein

\section{ABSTRACT}

In his writings about cinema, Jean Epstein poetically explained that every film contains a 'tragedy in abeyance' that is not explicit in the narrative. This cinematic idea guides the analysis of the films Cándida (1939) and Cándida millonaria (1941), two of three comedies that Luis Bayón Herrera directed about a Galician maid in Buenos Aires. Niní Marshall plays Cándida, a newcomer to Argentina who projects the stereotype of the female Galician immigrant. In these films Cándida faces two tragedies: that of a newcomer in an alien society and that of assimilation, which endangers the identity of the immigrant striving to fit into this new society. Drawing on Epstein's concept of photogénie, this article explores the representation of an almost invisible 'other' -a female, immigrant, domestic worker who is part of an ethnic minority- and the contradictions implicit in her comic portrayal.

Keywords: cinema, emigration, assimilation, Galicia, Jean Epstein

\section{Introduction}

Jacques Rancière' recalled the words of Jean Epstein in 1921 about the tragedy in duration when reflecting on the idea of cinema as a fable. This tragedy suspended in time reveals the intimate texture of things, opposed to the Aristotelian conventions that demand the action to develop, as if stories could have a real closure. Epstein considered that cinema:

does not render stories well. And 'dramatic action' is a mistake here. Drama that acts is already half 
resolved and on the healing slope to crisis. True tragedy remains in abeyance. It threatens all the faces. [...] Now the suspense is at freezing point. Waiting. One sees nothing as yet, but the tragic crystal which will create the nucleus of the drama has begun to form somewhere?

The true tragedy is revealed therefore in the objects about to fall, in the slight change of expression in a face, in the telephone waiting to ring. At the same time, cinema genres, still in formation in Epstein's era, try to suppress any slight sign of ambiguity if it is not justified in the script. In Rancière terms, the suspension conveys real life as opposed to the action of the cinematic expression, a sort of subtle filter of some suppressed truths, because the art of images is often fed with unpleasant ideas and situations. In this vein, genres such as comedy or melodrama, although considered harmless due to their intentions to entertain, can shed some light into aspects of the stories they tell and the periods they portray and, more importantly, into the ideologies implicit in their creation.

This idea of 'tragedy in abeyance' will guide the analysis of two of the 10 films in which Cándida appears, the character of a Galician maid in Buenos Aires created by the actress Niní Marshall. Although the films Cándida (1939) ${ }^{3}$ and Cándida millonaria/ Cándida the Millionaire (1941) ${ }^{4}$ are conventional comedies with a leading character, tragedy comes across in the face of Cándida and in the life of some common objects that display a hidden pattern in the films. The photogénie of Cándida, to use other of the terms of Epstein's theory ${ }^{5}$, is also part of the cinematic rendering of the maid in the films, as her face condenses the real life of the character. The quality of Marshall's expression combined with the formulaic execution of the films put into images the inseparable Siamese twins that are art cinema and industry that, as Epstein claimed, no surgeon could separate ${ }^{6}$.

Niní Marshall (the artistic name of María Esther Traverso) became one of the most shinning stars in the golden era of Argentinian cinema. She performed in radio, cinema and, finally, television a series of characters that represented the social diversity of Buenos Aires in the 1930s. The success of Marshall relies on her mastery of codeswit- ching and slapstick, a combination of verbal and physical humor. She was called a "Chaplin con faldas" [Chaplin with skirts] in the media but her comic style lends itself to a more accurate comparison with the Marx Brothers.

Cándida appeared for the first time in the early 1930s on the radio station Radio Municipal in Buenos Aires performing a secondary role in the radio drama El chalet de Pipita/Pipita's chalet' a soap where a Galician maid was the comic counterpoint. This role created by Niní Marshall was inspired by the Galician servant she had grown up with, Francisca Pérez, but also conveyed the most common features of Galician emigrants. In fact, the name of the role Cándida-Candid-connotes innocence, one of the characteristics of newcomers to a metropolis. Together with naïveté and fear, the thousands of Galicians who arrived in Argentina for centuries were seen as ignorant, dirty, pious and stubborn, but also hard-workers and loyal. Considering males in particular, Pérez Prado explains that the gayegos, Spanish by extension, but particularly the native Galicians were:

Dirty, mean, resourceful -sometimes-, brutish always- and coarse, but skilled for small businesses and cunning enough. There was no reason to fear them. In characterization and drawings they were represented with a squared and big head -like a cube - and a very characteristic feature: a long and very hairy monobrow, as a visor over 'moorish' eyes ${ }^{8}$.

Núñez Seixas describes the Galician women stereotype as:

Simple, ignorant characters, more or less yokels -although they experience a certain upward mobility-, and more greedy than Galician men and, on occasions, potentially amoral or close to the dangers of prostitution ${ }^{9}$.

As with any given stereotype, the Galician woman has certain features related to reality. The profession of Cándida is not trivial, and derives from the demographics of the Galician migration to America at the beginning of the Twentieth century. Most of the women looked for jobs in urban areas, where most of them, $42 \%$ between 1890 and 1900, were artisans and skilled factory workers, while at least $27 \%$ of them were employed in domestic service ${ }^{10}$. The image of the Galician 
maid prevails in the collective imagination 'not only because of the real facts, but also derived from the feeding of the stereotype in advertising and popular literature' "11. The most negative traits of the stereotype of these immigrants are related to the scarce formal education and the roughness of their behavior, 'that made them unable to develop any other job different from the help'12 As Spanish was not their mother tongue, Galician emigrants spoke a language crowded with phonetic and grammatical mistakes, interpreted as a sign of ignorance by locals ${ }^{13}$, and were used as a source of linguistic humor in theatre plays, radio broadcasts and films ${ }^{14}$. These linguistic anomalies were therefore an important source for literary humor and an essential inspiration for gags in audiovisual media.

Cándida was the cinematic result of a tradition of stereotyped roles of immigrants in the popular arts, inherited from the Spanish emigrants, which had its finest expression in the sainete criollo [creole one-act farce] ${ }^{15}$. The 'sainete criollo' put on stage some ethnic characters from Argentinian society at the beginning of the Nineteenth century in the conventillos, the neighborhoods that grouped the different ethnic origins in the cities. Galician servants, both men and women, 'are generally an archetype of honesty and faithfulness ${ }^{\prime 16}$ or 'innocent and harmless' people ${ }^{17}$. The dumb Galician maid was a 'long-standing stage character' 18 that became a cultural cliché in the country. The success of Cándida, firstly in radio broadcast and later in cinema, contributed to the strengthening of the stereotype.

From the 1950s onwards, the figure of the gayego, that was an inevitable part of the domestic work in Argentina, started to disappear due to the drop of migration and to the social mobility ${ }^{19}$. The Galician perfect maid is substituted for the cabecita negra [Little Black Head], a local mixed race woman, that has been recently portrayed in films like La ciénaga/ The Swamp (Dir. Lucrecia Martel, 2001)20 or Cama adentro /Live-in Made (AKA Señora Beba, Dir. Jorge Gaggero, 2004)21 in Argentinean cinema.

\section{The help in popular genres: the sup- porting roles of the subaltern class}

The character of the maid has been a constant in comedy since Commedia dell'Arte where, under several different names played, the role was always visible in a fixed pattern of interactions. Franchescina, during the 1600s, and Colombi$\mathrm{na}$, in the 1700s, are the smart lady maids that acted as the go-between for the young lovers. While in the first versions of the character the servetta is an old lady with certain life experience, the Colombinas are often younger and more sexualized. We can claim that these two types of theatrical maids are the most common portraits of the feminine help in cinema. As with their representations in Commedia dell'arte, they often play an important role for the development of the plot, but this is peripheral rather than central ${ }^{22}$. The female servant therefore does not acquire the status of an individualized character as Arlecchino and remains in a subaltern position ${ }^{23}$, although 'Colombina has the right to occupy the central crossing of these lines whenever she is on stage ${ }^{\prime 24}$.

The New Comedy described in the Tractatus Coislinianus staged the conflict between two generations, in a line of action where the oldest try to impede the love between the youngest. As with Commedia dell'Arte, the help plays a secondary but crucial role in the development of the story. Levin ${ }^{25}$ explains the operational system of the New Comedy with a triangle of forces where the servants become allies of the youngsters towards the inevitable happy ending. According to Levin, changes in identity are one of the most important themes in comedy and often this transpires with the marriage of two of the characters. In the plots the decadent power of the older generations is often usurped by lovers disguised as servants and vice versa.

Classical comedy in cinema adopted this same script: servants are the counterparts of their masters, a comic line of action that relaxes the melodramatic situations that provoke the evolution of love affairs. As Bordwell, Staiger and Thompson outline:

The classical film has at least two lines of action, both causally linking the same group of characters. Almost invariable, one of these lines of action 


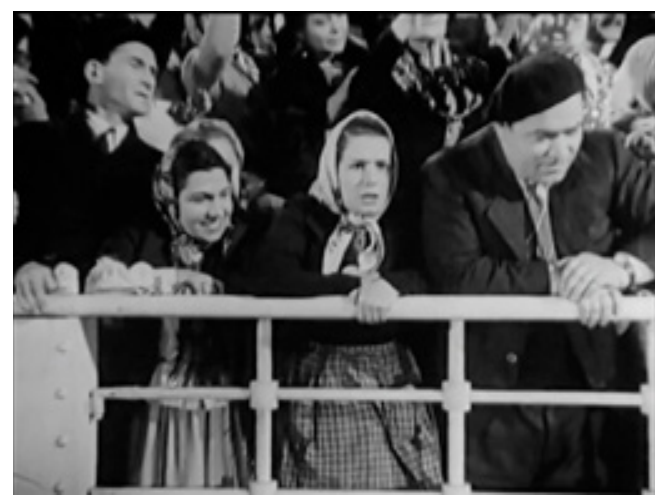

Fig. 1. Cándida (Luis Bayón Herrera, 1939). The amazed and terrified look of Cándida to Buenos Aires from the deck of the ocean liner

involves heterosexual romantic love. (...) We sometimes think of a play's second line of action as an independent subplot, such as comic love affair between servants. Classical Hollywood cinema, however, makes the second line of action casually related to the romantic action. Instead of putting many characters through parallel lines of action, the Hollywood film involves few characters in several interdependent actions ${ }^{26}$.

Cinema thus interweaves the different plots but keeps the position of the servants as secondary, at the same time it progressively transforms servants into employees of different kinds of businesses and ugly friends of the heroes.

The triangle old-young-help tended to reproduce the imbalance between social classes in the home and the confusion that generates a mixture of the private and professional spheres in the case of the servants. In this sense, the sociologists understand that the maid is treated as 'part of the family' and a worker at the same time, and both roles alternate depending on the needs of the household ${ }^{27}$. Anderson claims that "it is the worker's "personhood", rather than her labour power, which the employer is attempting to buy, and that the worker is thereby cast as unequal in the exchange" 28 .

The same thing that Antonio Gramsci said about the Italian emigrants in the 1930s can be applied to the Galicians who migrated to the Americas. Gramsci explains that capitalism dragged the working class to emigration and

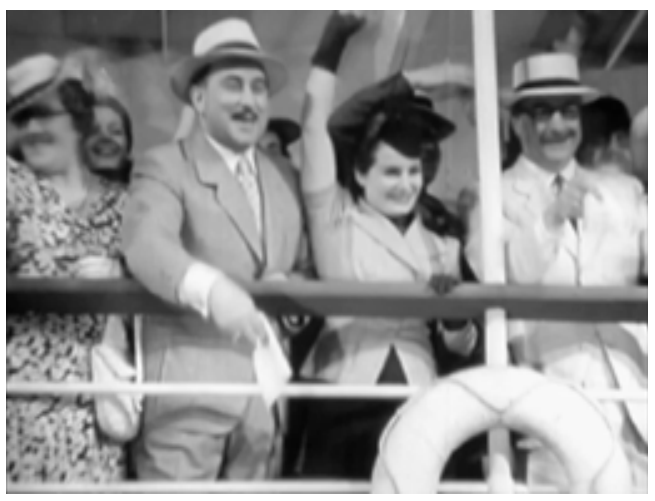

Fig. 2. Cándida Millonaria (Luis Bayón Herrera, 1941). The happy faces of Cándida and Marcial returning to Buenos Aires after their honeymoon

they joined their new societies 'in a subaltern function'29. The help is clearly portrayed as a subaltern class, using Gramsci's terms, holding a subsidized position, with spontaneous and episodic prominence. Just the same as Gramsci understood that the feuilleton was an appropriate cultural form to explain certain subaltern manifestations, popular cinema, namely comedy and melodrama, are ideal genres to recreate the lives of the subordinate.

The somehow unusual prominence of a character like Cándida can be understood in the same contradictory way as her duties as a maid imply. In a way, her sole presence as a leading character in a series of films could be subversive as she comes to the front line while her masters remain in a secondary position. Nonetheless, we will argue that the tragedy of the maid remains in abeyance while the melodrama of the ruling classes guides the action in the films towards their happy ending.

\section{Cándida and Cándida millonaria. From the steerage to the luxury liner}

The photograph that Joseph Stieglitz took in 1907 titled 'The steerage' became an iconic image of the migrant experience of Europeans to America. In the picture of the liner Kaiser Wilhem II, there is the since familiar scene of the passengers who paid the lowest fee for a transatlantic journey frequenting the lower deck of the steerage. The terrifying voyage was the first encounter many emigrants 


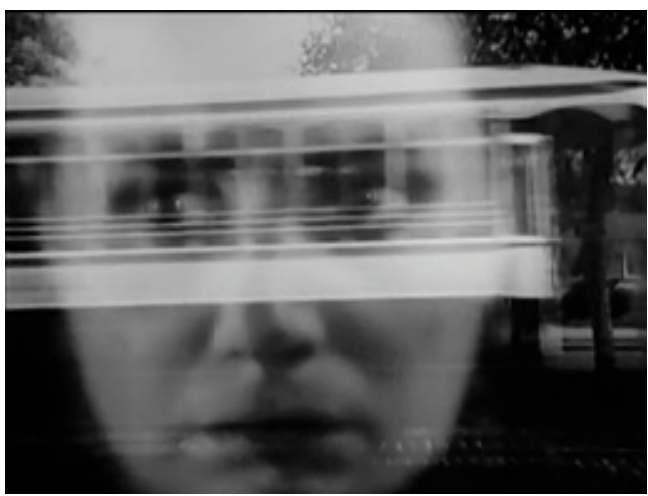

Fig. 3. Cándida (Luis Bayón Herrera, 1939). Overlapped shots of the protagonist in the middle of the traffic as she faces the city for the first time

had with foreign cultures and languages, a small practice for the great shock of the first sight of a metropolis such as New York or Buenos Aires.

It is precisely this gaze from the bridge of the ocean liner as a key shot in Cándida (1939) that dialogs with a parallel in Cándida Millonaria/ Cándida the Millionaire (1941) and is the starting point of our analysis. Both shots represent the two tragedies in abeyance of the character; in the first one, the tragedy of the newcomer; in the second, the tragedy of assimilation and somehow the loss of identity (figs. 1 and 2).

Cándida (1939) could be an accurate example of the difficulties faced by the emigrants when they arrive in a foreign land. The heroine arrives in Argentina looking for a job as a maid. She starts working really hard for a recent widower with three small sons, who will soon remarry another younger widow endangering the economy of the household in her attempt to climb in the social ladder. After the confrontation of the two women of the house, Cándida saves them by secretly paying their debts with her own savings that she had amassed for a future with her boyfriend Jesús.

The first sequence of Cándida (1939), directed and written by Luis Bayón Herrera from the story of Hernán de Castro and Niní Marshall, takes place in the steerage, where we can see the character from the first time. Her presentation is a vertical shot that starts at her feet to slowly show the physical appearance of a frightened presence,

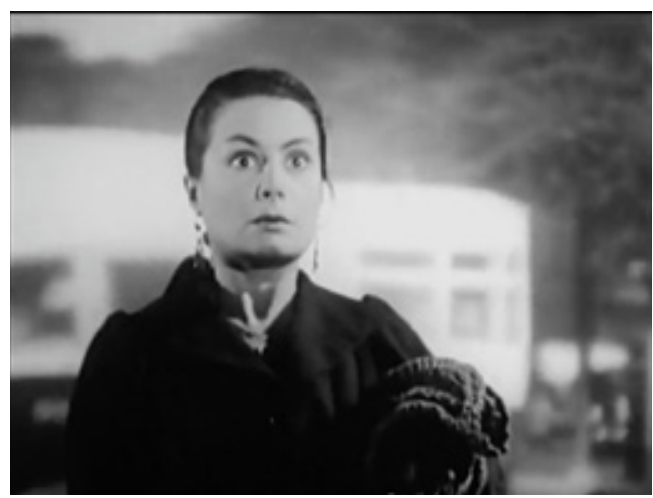

Fig. 4. Cándida (Luis Bayón Herrera, 1939). The photogénie of Cándida in the streets of Buenos Aires

portrayed in a ladder, a symbol of the so-called indecision of the Galicians. The soundtrack that accompanies her is the sound of bagpipes, the Galicians most iconic musical instrument, in a comic overture that leaves no doubt about the ethnicity of the character. From that portrayal, the audience knows that all the comedic elements of the story will derive from her ethnicity and the features attributed to its stereotype.

The shot of Cándida looking from the cruiser opens a brief dramatic sequence where the newcomer becomes aware of the difficulties of the new environment: from the images of her night's dream at the Hotel de Inmigrantes ${ }^{30}$, where Cándida is back in Galicia cuddling a piglet, there is a sharp transition to blurry shots of her in the middle of the traffic, which were shot with a truca for the first time in Argentinian cinema ${ }^{31}$ (fig. 3). Her anguished face in the shots contrasts with the relaxed expression in her dream and show that her position in the city will be a frail one. This presentation of the character, that will be getting blurred in the following films towards a disfigured Cándida in Cleopatra era Cándida (1964)32, is focused in the face of Niní Marshall. While her photogénie fills, the screen the conventional plot starts to develop in a contradiction between the suspended tradegy of the face and the melodramatic narrative that will end in a bittersweet conclusion for the heroine (fig. 4).

Cándida millonaria/ Cándida the Millionaire, also directed by Bayón Herrera, who writes the 
screenplay with Pedro E. Pico, has a parallel sequence at the beginning of the film. The story is disconnected from the previous film with Cándida as the leading role, Los celos de Cándidal Cándida's Jealousy (1940), when the maid has married her boyfriend Jesús in the first film and manages a guesthouse. In Cándida Millonarial Cándida the Millionaire (1941), the action starts with the heroine again in the ranks of the help, in the house of a rich widower businessman. It is Christmas Eve and Marcial, a Galician millionaire, discovers that he is spending the night alone. In the same hazy shots of Cándida (1939), Marcial walks the streets of Buenos Aires, cutting a solitary figure in the crowd.

Their pictures as social misfits last just a few seconds, a tragedy in abeyance subsumed in a conventional comic narrative. Within both films, as we will see, their strategies to fit in are dissimilar but converge with their wedding in Cándida Millonaria/ Cándida the Millionaire (1941).

During the story of the first film of Cándida, plot and relations with other characters will determine her portrait as the stereotypical mucama gallega [Galician maid]: dirty, ignorant, nosy, but honest and loyal to death.

Some scholars have seen her argumentative character, one of the most important sources of the verbal humor in the narrative, as proof of the empowerment of women. In her analysis of the character in her radiophonic version, Ehrick understands that Cándida defies class and gender schedules with her attitude:

Cándida is not the kind of woman to accept slights from her social superiors, she gives it right back in a way that reinforces the right of her voice to name and ridicule, and therefore asserts her equality in the public soundscape. The fact is that this battle of words and wits in a tie articulates that the balance of forces (class and maybe even gender) was shifting in Argentina ${ }^{33}$.

Although the attitude of Cándida is somehow defiant, her subaltern position is not just derived from gender and class, but mainly from her ethnic origins. Under this light, the character is not perceived as emancipated but just the opposite. Although Ehrick only refers to the controversy that stirred the Marshall's character of Doña Pola, a Jewish old lady, a significant group of the Galician community felt disrespected by Cándida ${ }^{34}$. Although the intellectuals and journalists of the immigrant community worked on campaigns against the character, critics praised the quality of the impersonation of a regular Galician woman.

The problem of identity is thus central to the analysis of the character Cándida. It is interesting to note that apparently she neither disowns nor feels ashamed of her origin but the character is surrounded by what Fernández Santiago ${ }^{35}$ regards as outcasts that hide their ethnic origins to climb in the social ladder.

The first encounter between Cándida and her soon-to-be boyfriend Jesús perfectly depicts the tension of identity in that multicultural society. Jesús tries to seduce the newcomer by showing off, performing as a true Argentinean. His tag line 'como hacen/dicen los americanos' ['as Americans do/say'] is humorous because all his attempts to look like a local are contradicted with the rest of his lines, in which he unsuccessfully tries to hide Galician language. Cándida's punchline, that turns her into the winner of the verbal battle, mocks the attempts of Jesús to impress her: 'Pues como dicimos (sic) los gallegos: que te parta un rayo!' 'Well, as Galician say, damn you!'.

The same as Jesús, Marcial, the male protagonist in Cándida Millonaria/ Cándida the Millionaire (1941), found his way to assimilation in this society through economic success. While Jesús is depicted as a ridiculous aspirant, Marcial is an entrepreneur that acquires social status with his factory and his changes in manners. Although Marcial, who is successfully acriollado (becoming Argentinean), adapted to the Argentinean society, he does not neglect his responsibilities as part of the immigrant community. His employees in the panties factory La Pecadora (the Sinner) are supposedly Galician women, as is demonstrated by the cry -half in Spanish half in Galician- when one of them receives the Christmas tip: 'Viva la nacionciña!' 'Hurra for the nation!'.

Cándida points to this transformation in their first encounter:

Cándida: Si parece talmente un compadrito de los de aquí... [If you look just like a local compadrito...]. 
Marcial (proudly): No tanto, muchacha, no tanto... [Not that much, girl, not that much...]

Cándida: En el habla, digho (sic) [For the language, I mean].

Marcial: Ah, vamos... [Oh, come on...].

Cándida: $y$ en la fachenda [and for the pride] (...)

While Galician men scaled social positions (or dreamed about it) with work and money, the only way for women to do so was through family relations. Cándida's life changes come with marriage in these two films, the only possible way to leave the help or start a new profession.

In Cándida Millonaria/ Cándida the Millionaire (1941) the denial of Galician identity is personified in the character Ana María, the daughter of Marcial. She does not only consider herself an Argentinean but she also despises her family origins, impersonated in the character of Cándida. Their relationship, first as employer and employee and later in the plot as stepmother and stepdaughter, bring to the forefront class tensions. It also shows the fears of the assimilated Galicians, who wanted to differentiate themselves from the newcomers or from those who remained alienated.

The reaction of Ana María when she finds out that her father is marrying Cándida is epitomised in these lines of dialog:

Ana María: Esta mujer es indigna de ti y de mi [This woman is beneath you and me].

Marcial: Ana María!

AM: ¡Una palurda impresentable! [A disgraceful yokel!]

M: ;Cállate! [Shut up!]

AM: ¡Una palurda! ¡ Una palurda! [A yokel! A yokel!]

M: Asi era tu madre... cuando fue tu madre. [Your mother was like that, when she was your mother]

Marcial stands between two worlds and he is uncomfortable in both while Cándida is judged as a carpetbagger who takes advantage of the private sphere of her job. Their hidden romance is censored by the rest of the help of the house who stress that Cándida is gallega, as if her ethnicity could be related to the fact that she is "available" for the sexual needs of the master. Research

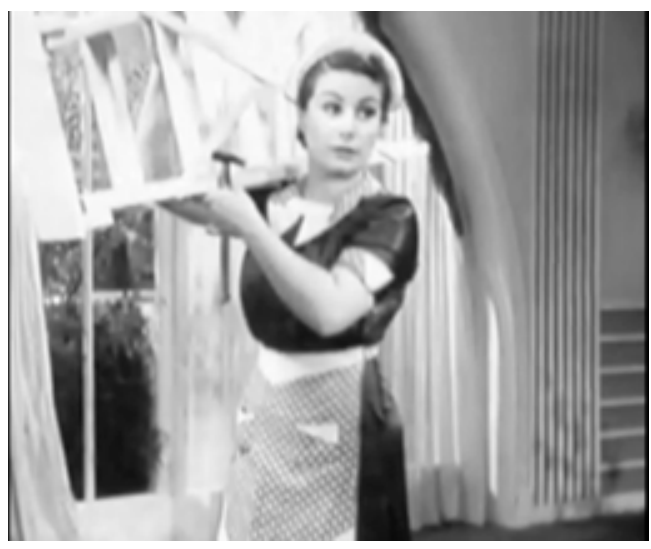

Fig. 5. Cándida Millonaria (Luis Bayón Herrera, 1941). Cándida carries a symbolic ladder to change her status from maid to wife in the film

shows that many of the Galician maids were asked to be the sexual initiators of the teenagers of the household or perform entertainment for their masters ${ }^{36}$. Other voices like Moya contend that the idea of the maid sexually involved with the household "may reveal more about social fears, male fantasies, and fetishes (...) than about the actual lives of most maids" ${ }^{37}$.

The only sexual allusion in both films is a scene where Marcial and his friend Benito look at the legs of Cándida while she hangs a curtain. Once again, a ladder, the same as in the opening scene of Cándida, works as an ordinary object which plays a hidden symbolic role in the narrative (fig. 5). The object and the relations of the characters to them mentioned by Epstein acquire here an important say in the fate of the character. When climbing to the tread, Candida's silk panties, too luxurious for a maid, become a subject of speculation for the daughter of Marcial and the help. The reaction of Cándida in the following scene reveals honesty as another of the features related to the Galician stereotype. The maid fights tooth and nail to demonstrate that she is an honest Galician, although it will be clear in the following scenes that she is involved with her boss.

Her marriage to Marcial positions her as the new lady of the house, an elegantly dressed newlywed on the bridge of the ocean liner on her honeymoon. This shot is analogous with that in Cándida (1939), where the heroine is dressed 
in the typical Galician outfit, anxious and terrified with the sight of the city. In Cándida Millonarial Cándida the Millionaire (1941) there is no memory of that moment, just the melodramatic absence of Ana María, who rejects her father for his marriage to Cándida.

Although Cándida has involuntarily climbed the social ladder, she will still be under scrutiny by the Argentinean high class she aspires to. Her aspirations are naïve, as the stereotype reflects: Galicians could be stubborn and sometimes rude but they are harmless. The repetition of the line 'she is so good...' in both films anticipates Cándida's final actions in them. The maid, as a 'good savage', performs a great sacrifice in Cándida (1939) where she saves her masters from ruin by secretly paying a debt with all her savings. In Cándida MiIlonaria/Cándida the Millionaire (1941), the maid who has become the lady of the house buys with her wedding presents the letters with which a former lover tries to blackmail Ana María. In both cases, Cándida pays a price for being recognized as a loyal part of the household, as maid and as wife, but she is distinguished as a 'good woman', yet only inferior to the worldly masters of the first film and the estranged daughter in the second.

\section{Conclusions}

Epstein claimed that there are not films that end badly, and happiness is achieved at the hour appointed in the programme. The happy ending in the films performed by Cándida hides the contradiction between her tragic renounces in order to be accepted and her comic inability to fit into a new society. Although Cándida is the leading role in both films, the ending returns the story to the hegemonic narrative of classical comedy and melodrama: the action of the maid plays a crucial part in the resolution of the plot, where the stability of the nuclear family is restored.

The maid becomes visible and improves her life standards -she marries and starts a business with Jesús in Cándida (1939), and she becomes a millionaire by marrying Marcial- but she remains Galician, the cause of the inferiority she suffers. The tradition of the Galician comic stereotype in theatre and radio broadcasting is perfected in the films of Niní Marshall, where Cándida becomes a subaltern heroine, if that oxymoron can even be possible. The role of the mucama gallega represents the tragedy of immigrants who, unable to go back to their homeland, had to survive in a society which despised them and therefore forced them to lose their identity by problematically aspiring to assimilate their new culture. It is not the straightforward narrative what allows the audience to know about this tragedy but the face of the maid and her relation to the surrounding atmosphere. Niní Marshall's photogénie contradicts therefore the happy ending by showing the suspended tragedy of the emigrant and the subaltern. 
NOTAS

Rancière, Jean. 2005. La fábula cinematográfica. Reflexiones sobre la ficción en el cine. Barcelona: Paidós.

2 Epstein, Jean. 1981. "Bonjour cinema and other writings." Translated from French by T. Milne. Afterimage, no. 10, 1981: 9-38.

3 Bayón Herrera, Luis. 1939. Cándida, Buenos Aires: Arte Vídeo.

4 Bayón Herrera, Luis. 1941. Cándida Millonaria/ Cándida the Millionaire, Buenos Aires: Arte Vídeo.

5 Epstein (1981: 20) describes as fotogenic "any aspect of things, beings or souls whose moral character is enhanced by filmic reproduction".

6 Epstein, Jean. 1981. "On certain characteristics of photogénie." Afterimage, no. 10: 20-23.

7 Cano, Josefa. 1930. El chalet de Pipital Pipita's chalet, Argentina: Radio Municipal.

8 Pérez-Prado, Antonio. 1993. "Imaxes da discriminación." Grial 31, no. 118: 212-221.

9 Núñez Seixas, Xosé Manuel. 2002. O Inmigrante imaxinario: estereotipos, representacións e identidades dos galegos na Arxentina (1880-1940). Santiago de Compostela: USC. Servizo de Publicacións e Intercambio Científico.

10 Cagiao Vila, Pilar. 1997. Muller e emigración. Santiago de Compostela: Xunta de Galicia.

11 Cagiao Vila, Pilar. 2007. "La experiencia argentina de las mujeres gallegas." In Buenos Aires gallega. Inmigración, pasado y presente, compiled by Ruy Farías, 155-166. Buenos Aires: Comisión para la preservación del patrimonio histórico cultural de la ciudad de Buenos Aires.

12 Cagiao Vila, Pilar. 2007. "La experiencia argentina de las mujeres gallegas." In Buenos Aires gallega. Inmigración, pasado y presente, compiled by Ruy Farías, 162. Buenos Aires: Comisión para la preservación del patrimonio histórico cultural de la ciudad de Buenos Aires.

13 Fernández Santiago, Manuel. 1995. "Unha aproximación á conside- ración social dos inmigrantes galegos en Arxentina." Grial 125: 95-114.

14 Previous to Cándida, the derogatory linguistic approach to Galician help was popularized in theatres, with characters as the maid Ramona, a character of the playwright ; Gallego y a mucha honra! (1929) by Emilio Paredes. The same name received another maid created by Mario Bellini as the main character of the sainete criollo [creole one-act farce] Ramona, which was premiered at the Teatro Comedia in Buenos Aires in 1931. Before the debut of Cándida in cinemas in 1939, the Galician made created by Niní Marshall was already well known by the Argentinean audience because of her appearances/performances in El chalet de Pipita, a radio production of the Broadcasting Municipal Station where Marshall worked since 1936 . The phonetic and grammatical mistakes of Galician migrants promptly spread from plays and radio productions to cinema representations, as we can see in the second "talkie" in the Argentinian cinema history. In Los tres berretines (Dir. Enrique Susini, 1933), written by Arnaldo Malfatti and Nicolás de las Llanderas, the renowned Argentinian actor Luis Arata performs the role of Manuel Siqueira, a Galician owner of a warehouse who suffers because his sons and daughters neglect the family business to focus on their three hobbies ('berretines'): tango, football and cinema.

15 Sempere, Isabel. 2002. "Niní Marshall o la imagen de la gallega en el cine argentino." In Universitas. Homenaje a Antonio Erias Roel, edited by C. Fernández Cortizo, D.L. González Lopo and E. Martínez Rodríguez, eds.), Tomo 2. Santiago de Compostela: Universidade de Santiago de Compostela, Servicio de Publicacións e Intercambio Científico, 273-287. Fernández Santiago, Manuel. 1995. "Unha aproximación á consideración social dos inmigrantes galegos en Arxentina." Grial 125: 95114. Lojo, María Rosa. 2008. "Los gallegos en la literatura argentina. Autobiografías y memorias." In Los "Gallegos" en el imaginario argentina. Literatura, sainete, prensa, edited by M.R. Lojo, M. Guidotti de Sánchez and R. Farias, 207-277. A Coruña: Fundación Pedro Barrié de la Maza.
16 Lojo, María Rosa. 2008. "Los gallegos en la literatura argentina. Autobiografías y memorias." In Los "Gallegos" en el imaginario argentina. Literatura, sainete, prensa, edited by M.R. Lojo, M. Guidotti de Sánchez and R. Farias, 54. A Coruña: Fundación Pedro Barrié de la Maza.

17 Moya, José. 1998. Cousins and strangers. Spanish Immigrants in Buenos Aires, 1850-1930, 226. Berkeley: California University Press.

18 Ehrick, Christine. 2015. Radio and the Gendered Soundscape. Women and Broadcasting in Argentina and Uruguay, 1930-1950, 148. New York: Cambridge University Press.

19 Lojo, María Rosa. 2008. "Los gallegos en la literatura argentina. Autobiografías y memorias." In Los "Gallegos" en el imaginario argentina. Literatura, sainete, prensa, edited by M.R. Lojo, M. Guidotti de Sánchez and R. Farias, 207-277. A Coruña: Fundación Pedro Barrié de la Maza.

${ }^{20}$ Martel, Lucrecia. 2001. La ciénaga. Lita Stantic Producciones, Argentina.

21 Gaggero, Jorge. 2004. Cama adentro /Live-in Made (AKA Señora Beba), Aqua Films.

22 Nicoll, Allardice. 1977. El mundo de Arlequín. Estudio crítico de la Commedia dell'Arte. Barcelona: Barral.

${ }^{23}$ Nicoll, Allardice. 1977. El mundo de Arlequín. Estudio crítico de la Commedia dell'Arte. Barcelona: Barral.

${ }^{24}$ Rudlin, John, and Crick, Olly. 2001. Commedia dell'arte. A Handbook for Troupes, 167. London-New York: Routledge.

${ }^{25}$ Levin, Harry. 1987. Playboys and Killjoys. An Essay on the Theory and Practice of Comedy. New York: Oxford University Press.

26 Bordwell, David, Staiger, Janet, and Thompson, Kristin. 1988. The classical Hollywood cinema. Films style and mode of production to 1960, 16. London-New York: Routledge.

27 Anderson, Bridget. 2000. Doing the dirty job? The global politics of domestic labour. London: Zed Books. Ehrenreich, Barbara, and Hochschild, Arlie Russell. 2000. Global women: nannies, 
maids, and sex workers in the new economy. London: Granta.

28 Anderson, Bridget. 2000. Doing the dirty job? The global politics of domestic labour, 2. London: Zed Books.

29 Gramsci, Antonio. 1999. Cuadernos de la cárcel, Tomo 2, 101. México D.F.: Biblioteca Era.

30 The 'Hotel de Inmigrantes' [Immigrants Hotel] was a benefit institution created in the early Twentieth Century to provide accommodation, medical care and administrative help to all the emigrants who arrived in Argentina. It was declared a National Historical Monument/Memorial in 1990 and since 1997 it has hosted the Museo de las Migraciones [Museum of Migrations].

31 Sempere, Isabel. 2002. "Niní Marshall o la imagen de la gallega en el cine argentino." In Universitas. Homenaje a Antonio Erias Roel, edited by C. Fernández Cortizo, D.L. González Lopo and E. Martínez Rodríguez, eds.), Tomo 2. Santiago de Compostela: Universidade de Santiago de Compostela, Servicio de Publicacións e Intercambio Científico, 273-287.

32 Saraceni, Julio. 1964. Cleopatra era Cándida, Argentina Sono Film S.A.C.I, Argentina.

33 Ehrick, Christine. 2015. Radio and the Gendered Soundscape. Women and Broadcasting in Argentina and Uruguay, 1930-1950, 150. New York: Cambridge University Press.

34 Pereira (2007) refers to the demonstrations by the Galician community at the premiere of Cándida millonaria/ Cándida the Millionaire on September 1941 protesting against the mockery of Galician women. In Pereira, P.B. 2007. "Cartas sin respuesta: intervenciones de gallegos a propósito de Cándida de Niní Marshall." In VII Congreso Nacional and Il Congreso Internacional de la Asocia- ción Argentina de Semiótica. Argentina: Rosario, 7-10 November 2007.

35 Fernández Santiago, Manuel. 1995. "Unha aproximación á consideración social dos inmigrantes galegos en Arxentina." Grial 125: 95-114.

36 Lojo, María Rosa. 2008. "Los gallegos en la literatura argentina. Autobiografías y memorias." In Los "Gallegos" en el imaginario argentina. Literatura, sainete, prensa, edited by M.R. Lojo, M. Guidotti de Sánchez and R. Farias, 207-277. A Coruña: Fundación Pedro Barrié de la Maza. Cagiao Vila, Pilar. 1997. Muller e emigración. Santiago de Compostela: Xunta de Galicia

37 Moya, José. 1998. Cousins and strangers. Spanish Immigrants in Buenos Aires, 1850-1930, 228. Berkeley: California University Press. 


\section{REFERENCES}

Anderson, Bridget. 2000. Doing the dirty job? The global politics of domestic labour. London: Zed Books.

Bayón Herrera, Luis. 1939. Cándida. Buenos Aires: Arte Vídeo.

Bayón Herrera, Luis. 1941. Cándida Millonaria/ Cándida the Millionaire. Buenos Aires: Arte Vídeo.

Bordwell, David, Staiger, Janet, and Kristin Thompson. 1988. The classical Hollywood cinema. Films style and mode of production to 1960, 16. London-New York: Routledge.

Cagiao Vila, Pilar. 1997. Muller e emigración. Santiago de Compostela: Xunta de Galicia

Cagiao Vila, Pilar. 2007. "La experiencia argentina de las mujeres gallegas." In Buenos Aires gallega. Inmigración, pasado y presente, compiled by Ruy Farías, 155-166. Buenos Aires: Comisión para la preservación del patrimonio histórico cultural de la ciudad de Buenos Aires.

Cano, Josefa. 1930. El chalet de Pipita/ Pipita's chalet. Argentina: Radio Municipal.

Ehrenreich, Barbara, and Arlie Russell Hochschild. 2000. Global women: nannies, maids, and sex workers in the new economy. London: Granta.

Ehrick, Christine. 2015. Radio and the Gendered Soundscape. Women and Broadcasting in Argentina and Uruguay, 1930-1950. New York: Cambridge University Press.

Epstein, Jean. 1981. "On certain characteristics of photogénie". Afterimage 10: 20-23.

Epstein, Jean. 1981. "Bonjour cinema and other writings." [Translated from French by T. Milne] Afterimage 10: 9-38.

Fernández Santiago, Manuel. 1995. “Unha aproximación á consideración social dos inmigrantes galegos en Arxentina." Grial 125: 95-114.

Gaggero, Jorge. 2004. Cama adentro /Live-in Made (AKA Señora Beba). Aqua Films.

Gramsci, Antonio. 1999. Cuadernos de la cárcel. Tomo 2. México D.F.: Biblioteca Era.

Levin, Harry. 1987. Playboys and Killjoys. An Essay on the Theory and Practice of Comedy. New York: Oxford University Press.
Lojo, María Rosa. 2008. "Los gallegos en a literatura argentina. Autobiografías y memorias." In Los "Gallegos" en el imaginario argentina. Literatura, sainete, prensa, edited by M.R. Lojo, M. Guidotti de Sánchez and R. Farias, 207-277. A Coruña: Fundación Pedro Barrié de la Maza.

Martel, Lucrecia. 2001. La ciénaga. Lita Stantic Producciones, Argentina.

Moya, José. 1998. Cousins and strangers. Spanish Immigrants in Buenos Aires, 1850-1930. Berkeley: California University Press. https:// doi.org/10.3138/cjh.34.1.145

Nicoll, Allardice. 1977. El mundo de Arlequín. Estudio crítico de la Commedia dell'Arte. Barcelona: Barral.

Núñez Seixas, Xosé Manuel. 2002. O Inmigrante imaxinario: estereotipos, representacións e identidades dos galegos na Arxentina (18801940). Santiago de Compostela: USC. Servizo de Publicacións e Intercambio Científico. https://doi.org/10.14198/pasado2004.3.15-6

Pereira, Paola Bibiana. 2007. "Cartas sin respuesta: intervenciones de gallegos a propósito de Cándida de Niní Marshall." In VII Congreso Nacional and II Congreso Internacional de la Asociación Argentina de Semiótica. Argentina: Rosario, 7-10 November.

Pérez-Prado, Antonio. 1993. "Imaxes da discriminación." Grial 31 (118): 212-221.

Rancière, Jean. 2005. La fábula cinematográfica. Reflexiones sobre la ficción en el cine. Barcelona: Paidós.

Rudlin, John, and Olly Crick. 2001. Commedia dell'arte. A Handbook for Troupes. LondonNew York: Routledge.

Saraceni, Julio. 1964. Cleopatra era Cándida. Argentina: Argentina Sono Film S.A.C.I.

Sempere, Isabel. 2002. "Niní Marshall o la imagen de la gallega en el cine argentino." In Universitas. Homenaje a Antonio Erias Roel, edited by C. Fernández Cortizo, D.L. González Lopo and E. Martínez Rodríguez, eds.), Tomo 2. Santiago de Compostela: Universidade de Santiago de Compostela, Servicio de Publicacións e Intercambio Científico. 
